\title{
HUBUNGAN KOMUNIKASI ORGANISASI DENGAN PENINGKATAN KINERJA KELEMBAGAAN DILINGKUNGAN PEMERINTAHAN DESA FIDITAN KECAMATAN PULAU DULLAH UTARA KOTA TUAL
}

\author{
Usman A. Matdoan \\ Stia Darul Rachman Tual-Maluku \\ E-mail: upagusman@yahoo.co.id
}

\begin{abstract}
Abstrak: Penelitian ini merupakan penelitian dengan menggunakan pendekatan diskriptif kualitatif yang bertujuan untuk menganalisis hubungan antara komunikasi organisasi dan kaitannya dengan kinerja kelembagaan pemerintahan desa. Hasil studi memperlihatkan bahwa aspek komunikasi organisasi berpengaruh positif terhadap kinerja kelembagaan pemerintahan di Desa Fiditan Kecamatan Pulau Dullah Utara Kota Tual.
\end{abstract}

Kata Kunci : Komunikasi, Organisasi, Kinerja.

\section{THE COMMUNICATION ORGANIZATION WITH INCREASING THE INSTITUTIONS IN THE VILLAGE ADMINISTRATION FIDITAN IN THE ISLAND DULLAH NORTH OF TUAL}

\begin{abstract}
The research is research with the use of an approach to a qualitative description aimed at peaceful and steady to analyze the relationship between communication the organization as well as relation to of institution performance of the village administration. The results of the study showed that there were a aspects of a communication of the organization of positive impact on the performance of their administrative institutions in the village Fiditan in the island Dullah North Of Tual
\end{abstract}

Keywords: Communication, Organisation, Increation.

Sebagai mahluk sosial manusia senantiasa ingin berhubungan dengan manusia lainnya. ingin mengetahui lingkungannya bahkan ingin mengatahui apa yang terjadi dalam dirinya. Rasa ingin tahu ini memaksa manusia untuk berkomunikasi. Dalam proses bermasyarakat orang yang tidak pernah berkomunikasi dengan orang lain niscaya akan terisolasi dari lingkungan sekitarnya. Banyak ahli menilai bahwa komunikasi merupakan kebutuhan yang sangat fundamental dalam hidup bermasyarakat. Wilbur (2005) misalnya menyebutkan bahwa, komunikasi dan masyarakat adalah merupakan dua kata kembar yang tidak dapat dipisahkan satu sama lainnya, menurutnya tanpa komunikasi tidak mungkin masyarakat terbentuk, sebaliknya tidak mungkin masyarakat dapat 
mengembangkan diri tanpa komunikasi. Komunikasi jelas tidak dapat dipisahkan dengan kehidupan umat manusia, baik sebagai individu maupun sebagai anggota masyarakat. Komunikasi diperlukan untuk mengatur tatakrama pergaulan antar manusia, sebab dengan berkomunikasi yang baik akan memberikan pengaruh langsung terhadap struktur keseimbangan seseorang dalam masyarakat.

Horal D. Laswel dalam Hafid Cangara (2004) menyebutkan setidaknya ada tiga fungsi utama yang mendorong mengapa manusia berkomunikasi, fungsi-fungsi dimaksudkan antara lain: Pertama, adalah hasrat manusia untuk mengontrol lingkungannya, melalui komunikasi manusia dapat mengetahui peluang-peluang yang ada untuk dimanfaatkan, dipelihara dan menghindar pada hal-hal yang mengancam alam sekitarnya. Melalui komunikasi manusia dapat mengetahui suatu kejadian atau perestiwa, bahkan melalui komunikasi manusia dapat mengembangkan pengatahuannya yakni belajar dari pengalamannya maupun melalui informasi yang mereka terima dari lingkungan sekitarnya. Kedua, adalah upaya manusia untuk dapat beradaptasi dengan lingkungannya. Proses kelanjutan suatu masyarakat sesungguhnya tergantung bagaimana masyarakat itu beradaptasi dengan lingkungannya, kemampuan beradaptasi disini tidak hanya terletak pada kemampuan manusia memberi tanggapan terhadap gejala-gejala alam, tetapi juga termasuk lingkungan masyarakat itu hidup.

Ketiga, adalah upaya untuk melakukan tranformasi warisan sosialisasi. Suatu masyarakat yang ingin mempertahankan keberadaannya, maka anggota masyarakat dituntut untuk melakukan pertukaran nilai, prilaku dan peranan. David K. Barlo (1965) secara ringkas menyebutkan bahwa komunikasi sebagai istrumen dari interaksi sosial yang berguna untuk mengetahui dan memprediksi sikap orang lain, juga untuk mengetahui keberadaan diri sendiri dalam menciptakan keseimbangan dengan masyarakat. Intensitas manusia dalam bekomunikasi terutama dalam menggunakan media komunikasi yang ada telah memperpendek jarak, menghemat biaya dan menembus ruang dan waktu. Proses komunikasi berusaha menjambatani antara pikiran, perasaan dan kebutuhan seseorang dengan dunia luarnya. Komunikasi dapat membangun kontakkontak manusia dengan menunjukan keberadaan diri dan berusaha memahami kahendak, sikap dan perilaku orang lain. Proses komunikasi membuat cakrawala seseorang menjadi semakin luas.

Secara konseptual komunikasi adalah suatu kegiatan yang dilakukan secara sadar, disengaja, serta sesuai dengan tujuan atau keinginan dari orang yang terlibat dalam proses komunikasi tersebut. Proses komunikasi dalam pengertian dasar adalah bahwa kegiatan komunikasi yang dilakukan seseorang sepenuhnya berada dalam kondisi mental psikologis yang terkendali atau terkontrol bukan dalam keadaan tidak sadar". Sedangkan disengaja dalam pengertian bahwa komunikasi yang dilakukan memang sesuai dengan kemauan pelakunya sementara tujuan berkomunikasi merujuk pada hasil atau akibat yang dinginkan dari proses komunikasi tersebut. 
Lembaga atau instansi pemerintah desa merupakan institusi formal ditingkat lokal yang memiliki tugas dan fungsi serta kewenangan untuk melaksanakan aktifitas pemerintahan dalam rangka memberikan pelayanan kepada masyarakat. Dalam kaitan diatas, secara harfia organisasi dapat difahami sebagai perpaduan bagian-bagian yang satu sama lain, saling memiliki ketergantungan. Sementara ahli lain berpendapat bahwa organisasi sebagai suatu struktur yang melangsungkan proses pencapaian tujuan yang telah ditetapkan dimana operasi dan interaksi di antara bagian yang satu dengan bagian yang lainnya dan manusia yang satu dengan manusia yang lainnya berjalan secara harmonis, dinamis dan pasti sangat membutuhkan suatu proses interaksi dan komunikasi yang bersifat dinamis pula.

Kemampuan struktur organisasi yang melangsungkan prosesnya secara tersistimatis tersebut akan dapat mencapai tujuan secara efektif, dalam pengertian input yang diproses secara baik akan menghasilkan output yang diharapkan sesuai dengan biaya, personil dan waktu yang direncanakan. Sesungguhnya keterkaitan antara proses komunikasi dengan organisasi adalah terletak pada manusia-manusia yang terlibat dalam usaha pencapaian tujuan organisasi itu. Aspek mendasar dari proses komunikasi dalam kaitannya dengan penyelenggaraan fungsi dan tugas organisasi adalah menyangkut pertanyaan mengnai bentuk komunikasi apa yang digunakan, bagaimana prosesnya dan faktor-faktor apa yang menjadi penghambat.

Salah satu faktor yang memiliki kaitan langsung dengan komunikasi organisasi adalah adalah hubungan atau pengaruh komunikasi terhadap organisasi, Wiliam V. Hannye dalam Riswandi (2009) menjelaskan bahwa "organisasi terdiri dari sejumlah orang, melibatkan keadaan saling bergantung, kebergantungan memerlukan koordinasi, koordinasi mensyaratkan komunikasi. Dan koordinasi diartikan sebagai kombinasi antara karyawan suatu organisasi, baik dalam hubungan secara timbal balik maupun secara horisental diantara para karyawan secara timbal balik disebabkan oleh adanya proses komunikasi. Dalam organisasi pemerintahan aspek penting dan mendasar yang perlu dilaksanakan oleh pimpinan kepada bawahannya adalah melalui proses komunikasi yang harmonis. Merujuk pada paparan diatas dan setelah dihubungkan dengan realitas dilapangan dapat diperoleh data bahwa kominikasi organisasi yang intens antara kepala desa dengan masyarakat di Desa Fiditan Kota Tual berdampak positif terhadap peningkatan kinerja kelembagaan pemerintahan desa.

\section{METODE PENELITIAN}

Metode atau pendekatan yang dipakai dalam menganalisis hasil penelitian ini, adalah dengan menggunakan desain diskriptif kualitatif yang dihubungkan dengan hasil observasi lapangan, dan kemudian membandingkan dengan kajian teoritis yang bertujuan untuk melihat relefansi antara kajian teori dan kondisi riil dilapangan. 


\section{HASIL DAN PEMBAHASAN}

Penelitian ini berusaha untuk menganalisis beberapa indikator dalam hubungannya dengan penerapan komunikasi organisasi dilingkungan pemerintahan desa Fiditan, untuk mendapatkan jawaban riil terhadap aspek komunikasi organisasi tersebut, selanjutnya dirumuaskan sejumlah pertanyaan yang kemudian ditanyakan kepada sejumlah responden yang dapat diharapkan dapat merepresentasi masyarakat maupun unsur pemerintahan desa, dimana rumusan pertanyaan disajikan dalam bentuk naratif, selanjutnya jawaban responden disajikan dalam bentuk grafik dengan suatu asumsi bahwa jawaban-jawaban responden tersebut lebih terukur. Selanjutnya responden yang ditetapkan terdiri dari 10 responden yang kemudian ditetapkan informan key, yang diharapkan dapat mewakili berbagai kelompok kepentingan di desa, misalnya unsur perangat desa, tokoh masyarakat, unsur pemuda dan unsur perempuan. Selanjutnya rumusan pertanyan dan jawaban responden adalah Sebagai berikut:

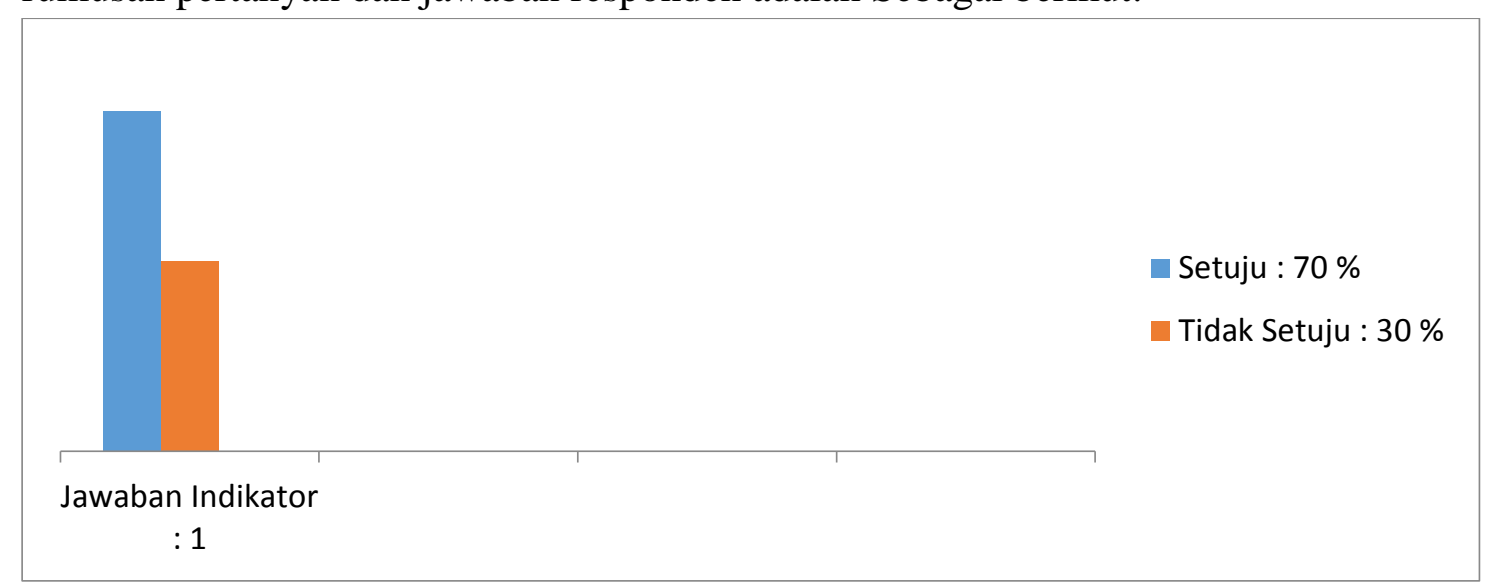

Gambar 1. Rumusan pertanyaan "Apakah penerapan sistem komunikasi organisasi dapat meningkatkan kinerja kelembagaan pemerintahan desa"

Melalui data yang ditampilkan pada grafik tersebut memperlihatkan $70 \%$ informan setuju bahwa komunikasi organisasi yang intens memiliki pengaruhi positif terhadap peningkatan kinerja kelembagaan pemerintahan desa, sedangkan $20 \%$ informan memberikan jawaban tidak setuju. 


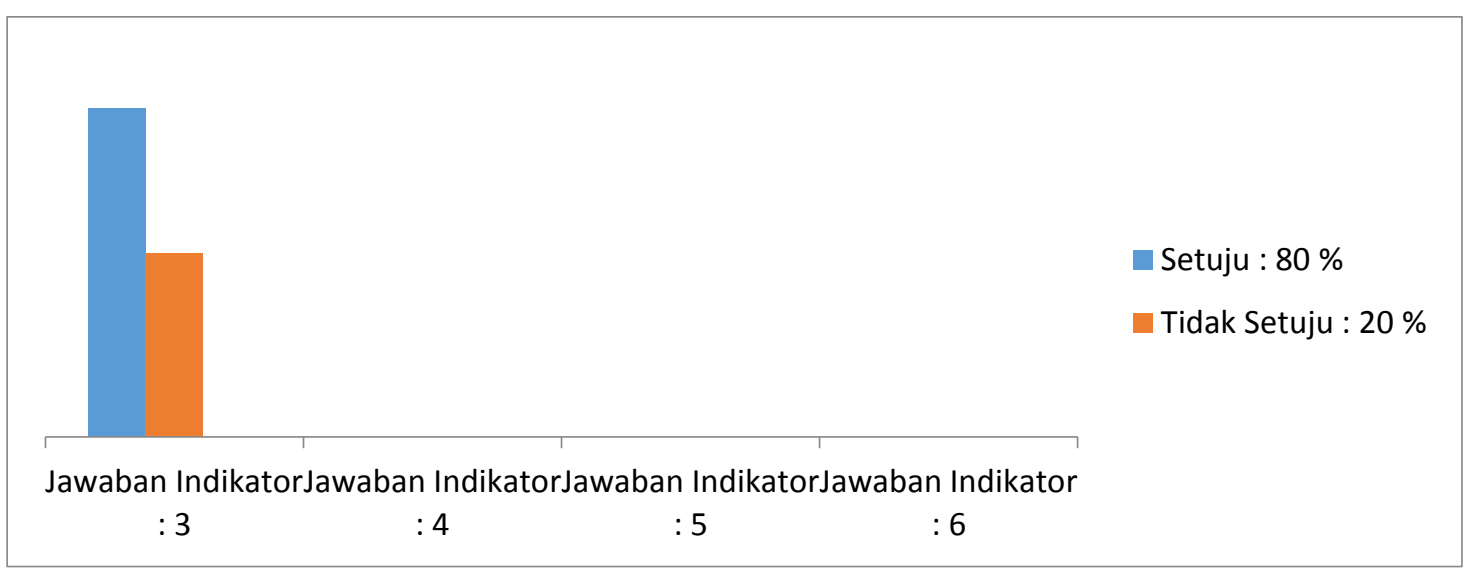

Gambar 2 Rumusan pertanyaan"Apakah penerapan sistem komunikasi organisasi dapat mempertemukan keinginan antara masyarakat desa dengan perangkat pemerintahan desa"

Tapilan data pada grafik tersebut, memperlihatkan bahwa $80 \%$ responden menyetujui kalau komunikasi organisasi dapat mempertemukan antara keinginan masyarakat dan perangkat pemerintahan desa dan ada $20 \%$ responden tidak menyetujui kalau faktor komunikasi sebagai satu indikator utama dalam mempertemukan keinginan masyarakat dan perangkat desa.

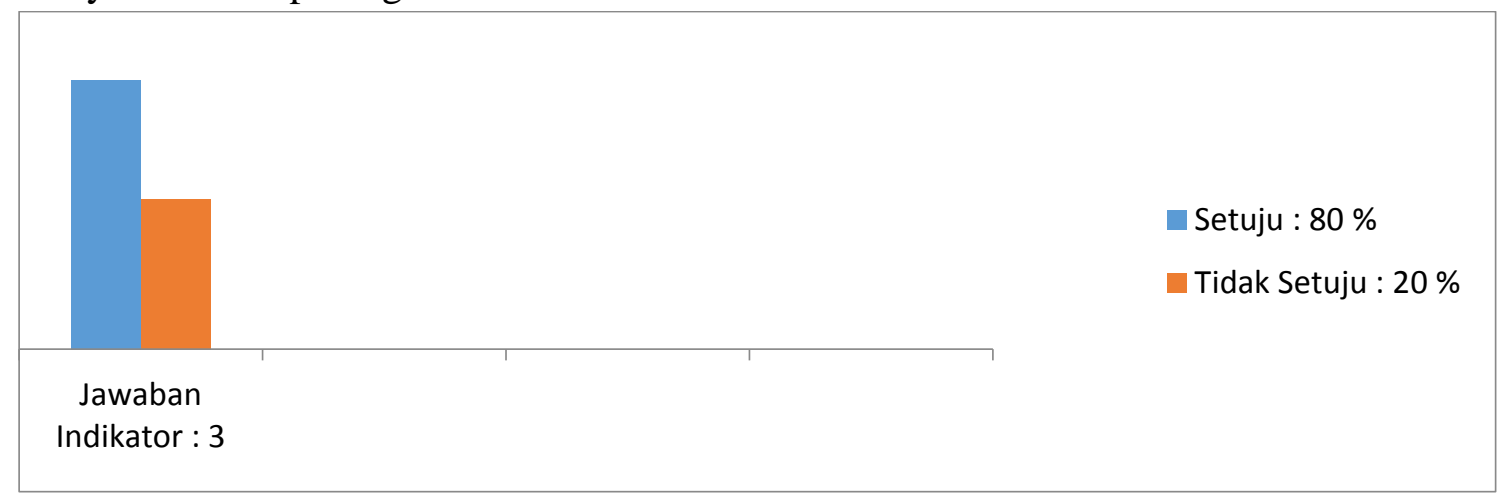

Gambar 3. Rumusan pertanyaan "Apakah penerapan sistem komunikasi organisasi dengan intens mendorong peningkatan kualitas komunikasi antara masyarakat dengan perangkat pemerintahan desa".

Berdasarkan jawaban responden pada grafik 3 tersebut, terlihat adanya $80 \%$ responden menyetujui bahwa penerapan sistem komunikasi organisasi yang intes berpengaruh positif terhadap peningkatan kualitas komunikasi antara masyarakat dan perangkat desa, dan hal ini kemudian berpengaruh positif terhadap peningkatan pembangunan desa secara keseluruhan, namun demikian masih terdapat $20 \%$ responden yang mempersepsikan bahwa keberhasilan pembangunan desa tidak semata-mata dipengaruhi oleh faktor intensitas komunikasi yang tinggi antara masyarakat dengan perangkat desa, tetapi ada variabel lain yang perlu diperhatikan

Carl Hovland, Janis dan Kelley (1993), bahwa komunikasi adalah suatu proses melalui dimana seseorang (komonikator) menyampaikan stimulus dengan tujuan 
mengubah atau membentuk perilaku orang-orang lainnya. Berelson dan Gary A. Steiner (1995), bahwa komunikasi adalah suatu penyampaian informasi, gagasan, emosi, keahlian dan lain-lain melalui pennggunaan simbol-simbol seperti kata-kata, gambar, angka-angka dan lain-lain. Wiaver (2001), komunikasi adalah seluruh prosedur melalui mana pikiran seseorang dapat mempengaruhi pikiran orang lain. Melalui definisi diatas, terlihat bahwa masing-masing ahli memberikan defenisinya sesuai dengan sudut pandangnya dalam melihat komunikasi. Masing-masing memberikan penekanan arti, ruang lingkup dan konteks yang berbeda. Semua penekanan itu menjelaskan bahwa tujuan komunikasi adalah mengubah atau membentuk perilaku. Komunikasi secara konseptual pada intinya adalah proses penyampaian informasi, gagasan, emosi, keahlian dan lain-lain.

Riswandi (2009), bahwa secara harfia, organisasi berarti perpaduan bagian-bagian yang satu sama lain saling bergantung. Ahli lain memandang organisasi sebagai suatu struktur yang melangsungkan proses pencapaian tujuan yang telah ditetapkan dimana operasi dan interaksi diantara bagian yang satu dengan yang lain dan manusia yang satu dengan yang lainnya berjalan secara harmonis, dinamis dan pasti. Mufid Muhammad (2005) menjelaskan bahwa kemampuan struktur organisasi yang melangsungkan prosesnya secara sistimatis akan dapat mencapai tujuan secara efektif, dalam pengertian input yang diproses akan menghasilkan output yang diharapkan sesuai dengan biaya, personil, dan waktu yang direncanakan.

Seperti telah dikemukakan pada bagian pendahuluan, mengenai hubungan komunikasi dengan organisasi, maka oleh William V. Hanney dalam Hafid Cangarah (2004: 116) menyebutkan bahwa, hubungan komunikasi dengan organisasi adalah bahwa "organisasi terdiri dari sejumlah orang, melibatkan keadaan saling bergantung, kebergantungan memerlukan koordinasi, koordinasi mensyaratkan komunikasi. Makna koordinasi dalam pengertian ini adalah kombinasi atau interaksi yang harmonis diantara para karyawan dalam suatu organisasi, baik dalam bentuk hubungan yang sifatnya vertical maupun hubungan yang sifatnya horosental, baik antara pimpinan dengan bawahan maupun antara bawahan dengan bawahan. Demikian pula interaksi antara pimpinan organisasi seperti manajer tingkat tinggi/top manajemen atau manajemen tingkat menengah dengan khalayak di luar organisasi.

Dalam konteks ini, seorang pimpinan organisasi, manajer, atau administrator harus memilih satu metode atau teknik komunikasi yang disesuaikan dengan kondisi atau situasi dimana proses komunikasi dilaksanakan. Dalam hubungannya dengan komunikasi organisasi, seorang top manajer atau seorang pimpinan harus menyesuaikan penyampian pesannya dengan peranan yang sedang dilakukannya. Henny Mintzberg (2001), bahwa wewenang formal seorang pemimpin menyebebkan timbulnya tiga peranan yang pada giliranya menyebabkan seorang pemimpin/manajer berperan untuk menentukan suatu keputuskan. Menurutnya karena pentingnya hubungan manajer sebagai pemimpin 
organisasi dengan komunikasi, maka peranan itu harus dijelaskan sehingga akan jelas pula pengaruhnya pada perilaku organisasional.

Terkait dengan wewenang formal dari seorang pemimpin oragnisasi secara langsung akan menimbulkan tiga peranan yang meliputi hubungan antarpersonal yang mendasar, yang meliputi: Pertama peranan sebagai tokoh, disebabkan kedudukan seseorang sebagai kepala unit suatu organisasi, seorang pimpinan harus terlibat dalam berbagai kegiatan yang bersifat serimononial baik dalam instansinya/organisasinya secara internal maupun di luar instansi atau organisasinya. Kedua berperan sebagai pemimpin, sebagai pemimpin, seorang manajer bertanggung jawab atas lancar tidaknya pekerjaan yang dilaksanakan bawahannya. Termasuk beberapa kegiatan yang berkaitan langsung dengan kepemimpinannya pada semua tahap manajemen berupa; penentuan kebijakan, perencanaan, pengorganisasian, penggerakan, pengawasan dan penilaian. Dan ketiga berperan sebagai penghubung, dalam peranannya sebagai penghubung seorang manajer melakukan komunikasi dengan orang-orang di luar komando vertical, baik secara formal maupun secara tidak formal. Dalam kaitan tersebut maka terdapt sejumlah hasil penelitian menunjukan bahwa seorang manajer menghabiskan waktunya untuk berhubungan dengan orang-orang di luar organisasinya sama dengan waktu yang dipergunakan untuk berhubungan dengan bawahannya.

Dalam suatu organisasi, seorang pemimpin/manajer berfungsi seperti pusat syaraf karena ia berada di tengah-tengah jaringan kontak dengan semua pihak yang ada kaitannya dengan organisasi. Ia mengetahui lebih banyak mengenai organisasinya daripada siapapun juga. Ia mengkomunikasikan informasi ke luar yang oleh bawahannya. Sebaliknya ia menerima banyak informasi dari luar yang oleh bawahannya jarang diperoleh. Komuniksi sering dilakukan oleh pemimpin dengan pemimpin lain yang sama statusnya yang juga merupakan pusat syaraf. Dengan demikian manajer tersebut melakukan dan mengembangkan pusat informasi terhadap kepentingan organisasinya. Henny Mintzberg (2001), bahwa perenan informasional seperti dikemukakan di atas, setidaknya memiliki tiga perenan penting yang dimainkan oleh seorang pemimpin/manajer, misalnya: Pertama peranan sebagai monitor, seorang manajer memandang linkungannya sebagai sumber informasi, ia mengajukan berbagai pertanyaan kepada bawahannya, dan ia menerima informasi pula dari mereka tanpa diminta melalui kontak pribadi yang selalu dibinahnya. kedua peranan manajer sebagai penghubung, sebagai penghubung seorang pemimpin atau manajer menerima dan menghimpun informasi dari luar organisasi untuk kemudian disebarkan kepada bawahannya. Pemimpin atau manajer tersebut mengkomunikasikan informasi yang diperolehnya dari luar kepada bawahannya karena para karyawan tidak banyak memiliki kesempatan untuk memperoleh informasi dari luar yang penring bagi kepentingan organisasi. Ketiga peranan sebagai juru bicara, peranan pimpinan atau manajer sebagai jurubicara memiliki persamaan dengan peranan sebagai penghubung, yakni dalam hal mengkomunikasikan 
informasi kepada khlayak luar. Perbedaannya ialah dalam hal caranya. Jika dalam peranannya sebagai penghubung seorang pemimpin/manajer menyampaikan informasi secara antarpersonal atau kontak pribadi dan tidak selalu resmi, maka dalam peranannya sebagai jurubicara seorang pemimpin/manajer tidak selamanya melakukan hubungan secara pribadi tetapi lebih bersifat resmi.

Peningkatan kinerja di dalam suatu organisasi tidak bisa dilakukan tanpa adanya pengelolaan atau manajemen yang baik, yang dapat mendukung upaya-upaya peningkatan kinerja. Pengelolaan atau manajemen tersebut harus merupakan suatu rangkian atau siklus yang secara sungguh-sunggu merupakan fungsi-fungsi manajemen, sekurang-kurangnya meliputi tahap perencanaan, pelaksanaan, dan pemantauan atau evaluasi. Kegiatan dimulai dari tahap perencanaan dan berakhir pada tahapan evaluasi kinerja. Hasil evaluasi kinerja tersebut selanjutnya menjadi masukan atau feedback bagi tahapan perencanaan berikutnya. Dengan demikian, manajemen kinerja diperlukan agar upaya-upaya peningkatan kinerja dalam suatu organisasi tertata dengan baik dalam suatu siklus tahapan kerja yang tak terputus (LAN. RI. 2004).

\section{KESIMPULAN}

Berdasrkan hasil analisis data, dapatlah ditarik kesimpulan dalam penelitian ini bahwa proses komunikasi organisasi akan memberikan implikasi positif antara masyarakat dan perangkat pemerintahan desa akan berdampak positif terhadap kinerja kelembagaan pemerintahan di Desa Fiditan Kecamatan Dullah Utara Kota Tual.

\section{SARAN}

Perlu adanya kajian yang lebih mendalam tentang proses komunikasi organisasi akan memberikan implikasi positif antara masyarakat dan perangkat pemerintahan desa sehingga dapat memajukan kinerja pemerintah dalam melakukan pelayanan kepada masyarakat.

\section{DAFTAR PUSTAKA}

Dhani Rendo. 2004. Centang Perenang Manajemen Komunikasi Presiden: dari Soekarno sampai Megawati. LP3ES. Jakarta

H. Hafeied Cangara. 2002. Pengantar Ilmu Komunikasi. PT. Raja Grafindo Persada. Jakarta

Henny Mintzberg. 2001. Goran Comunication and social Change in Devoloping. Nation

A. Critical View the Lowa State University Press. USA

Schramm, Wilbur. 1971. The Proses and Effects of Mass Comonicatian, University of Illinois Pres Urbana. Edisi Terjemahan

Lembaga Administrasi Negara (LAN). 2004. Sistem Administrasi Pemerintahan

Riswandi .2009. Ilmu Komunikasi. Graha Ilmu. Yogyakarta 